\title{
THE LEVEL OF ECONOMICS PARTICIPATION OF RURAL WOMEN IN DUHOK GOVERNORATE IN KURDISTAN REGION OF IRAQ AND ITS RELATION WITH SOME VARIABLES
}

\author{
Hashim Saeed Murad, Abid Ali Hasan Al-Doski ${ }^{*}$ and Aamel F. Khalil Al-Abbassi** \\ *Dept. of Agricultural Extension and Rural Development, College of Agricultural Engineering \\ Sciences, University of Duhok, Kurdistan Region-Iraq \\ ** Dept. of Agricultural Extension, College of Agriculture \& Forestry, University of Mosel-Iraq
}

(Accepted for Publication: October 21, 2019)

\begin{abstract}
Women play a vital role in economic activities. They compromise about $50 \%$ of the global total labor that engaged in agriculture and food production enterprises. This study is designed to determine the economic participation by rural women in Duhok governorate in Kurdistan Region of Iraq. The number of the respondents of this study was (474) were selected by area random sampling. SPSS software were used to analyze the data collected, statistics such as frequency, percentage, mean, standard deviation, correlation, and regression was used. The results shows that the perception level of respondents in economic participation is high. The results also show there is a significant relationship between some social, demographic variables and 'economic participation level such as (age, number of study years, satisfaction with services in the villages, urban openness) and non-significant with (living conditions of the family, fathers occupation or guardian, current job, ability to solve problems). It is recommended that the extension agencies should have a re-orientation of their Programs and activities, where women will be treated equally with their male counterparts. This will ensure more rural and agricultural development in the targeted area.
\end{abstract}

KEYWORDS: Rural women, participation, Agricultural Economic, Duhok.

https://doi.org/10.26682/cajuod.2020.22.2.9

\section{INTRODUCTION}

S ociety development depends on combination of two basic aspects; the people and the government, efforts by means of which, social, economic, cultural and psychological changes are materialized with an eye to improve and upgrade the status of the people of these communities. (Harbi 1997).

Women play crucial roles in the agricultural production in the developing countries, especially in countries with low income rate and where agriculture accounts for high ratio of the gross national production. Rural women represent the majority of the agricultural labor force in these countries because they produce the bulk of the locally consumed foods. This qualifies them to be one of the fundamental variables in achieving the economic development and family welfare in the rural communities Salih (2015). Curbing all their agricultural potentialities constitutes a contributing factor in the slowness of development and absence of food security. (World Bank, 2008)./II///The outcomes and recommendations, of many conferences and studies, highlight the need to pay attention to women and their participation in different aspects of, in order to achieve a thorough development. (Sherif, 2005).

In view of the considerable importance of the participation of rural women in the affairs of the local community, and in the light of economic significances.

Rural women as half of the rural population, have an important role in economic and social activities, and to achieve rural development requires more attention to women that are involved alongside and tandem with men in economic and social activities, in explaining the rural women's importance role in production is this. Thus we know that the achievements of the World Conference on the United Nations' Decade of Women, "which is entitled" Equality, 
Development and Peace "in 1980 was held in New York, was that two-thirds of the total work done by women in the world which rural women do most of this work. (Adisa, 2013). Therefore, if that overlooked women in the production and does not matter to their important role in development and economic status each type of planning will fails and always lags behind the country in general and the village in particular, or in other words their lack in field of different agricultural activities not only makes trouble the family in the area of functions that are responsible as a mother and wife but is serious as power-efficient and effective in terms of rural economic caused a crisis. (Das, 1995).

Women make essential contributions to the agricultural and rural economies in all developing countries. Their roles vary considerably between and within regions and are changing rapidly in many parts of the world, where economic and social forces are transforming the agricultural sector they often manage complex households and pursue multiple livelihood strategies therefor their activities typically include producing agricultural crops, tending animals, processing and preparing food, working for wages in agricultural or other rural enterprises, collecting fuel and water, engaging in trade and marketing, caring for family members and maintaining their homes. (Yousef Ghanbari1, Hamid Barghi2, Nafiseh ghotbinejad3, 2013)

Rural women participate to almost every agricultural activity both in all over the world. Especially in developing countries, women conduct irrigation activities or irrigation management successfully. On the other hand, women have big responsibility in a lot of production activities which needs intensive water use like fishery, cut flowers and garden, rice and etc. (Jonathan, 1998)

However, the rural women in the area of study are facing many problems. Among that is the adoption of technologies that has been transferred to them. Their knowledge and skills are low because of the lack of training from agencies to them and lack of activities. Therefore this study come to discover the situation of participation level toward economic activities in area of study for rural women and to see wither their level of participation in economic activities is high or low. Therefore, this research intends to contribute to the existing literature by providing an empirical analysis to detect the possibility of applying economic activities for rural women point of view.

\section{Objectives of the Study:}

The Main Objective of the study is to determine the economic participation of rural women in Duhok Governorate, the specific objectives are:

1. To identify the economic participation level by rural women in Duhok Governorate / Kurdistan region of Iraq.

2. To identify the relationship between selected characteristics of rural women and their degree of participation in economic activities.

3. To diagnose the obstacles of economic participation by rural women in Duhok governorate / Kurdistan region of Iraq.

\section{Methodology}

A total of (474) respondents were randomly selected from different rural areas of Duhok governorate representing of total rural women who were above 18 years as shown in table (1). The data has obtained through face-to-face interview based on a structured questionnaire which has been held from April to June 2018. Three Likert scale was used to identify the level of participation in economic activities of respondents. The Cronbach alpha value obtained for the scales was (0.750) exceeding. The collected data was subjected to data analysis including statistics such as frequency, percentage, mean, standard deviation, correlation, and regression using SPSS software.

Table (1): The population and sample size of the study

\begin{tabular}{|c|c|c|c|c|c|}
\hline No. & Area (districts) & Area (sub-districts) & Villages & $\begin{array}{l}\text { Number of women } \\
\text { above } 18 \text { years of age }\end{array}$ & $\begin{array}{c}\text { Size of Sample } \\
10 \%\end{array}$ \\
\hline & & Zawita & Mamani & 102 & 10 \\
\hline & & & Kora & 51 & 5 \\
\hline \multirow[t]{2}{*}{1} & Center of Duhok & Mangish & Banda & 78 & 8 \\
\hline & & & baroshka sadiny & 274 & 27 \\
\hline
\end{tabular}




\begin{tabular}{|c|c|c|c|c|c|}
\hline & & Center of & Sege & 251 & 25 \\
\hline \multirow[t]{4}{*}{2} & Semel & Semel & Qasir Yazdin & 96 & 10 \\
\hline & & Batel & Asahe & 84 & 8 \\
\hline & & & Simail Ava & 243 & 24 \\
\hline & & Rezkare & Feshkhbor & 180 & 18 \\
\hline \multirow[t]{4}{*}{3} & zakho & & Kraola & 94 & 9 \\
\hline & & Batifa & Zereza & 89 & 9 \\
\hline & & & Kashane & 37 & 4 \\
\hline & & Sarsing & Hamzike & 48 & 5 \\
\hline \multirow[t]{4}{*}{4} & amedi & & Skreen & 122 & 12 \\
\hline & & Deralok & Sargale & 134 & 13 \\
\hline & & & Goharze & 253 & 25 \\
\hline & & Atrosh & Kaline & 26 & 3 \\
\hline \multirow[t]{4}{*}{5} & Shekhan & & Harmash & 48 & 5 \\
\hline & & Baadre & Bstik & 51 & 5 \\
\hline & & & Isian & 339 & 34 \\
\hline & & Denarta & Kane Halan & 163 & 16 \\
\hline \multirow[t]{4}{*}{6} & Akre & & Glbish & 116 & 12 \\
\hline & & Gardasin & Sisna & 236 & 24 \\
\hline & & & Similan & 117 & 12 \\
\hline & & Darato & $\begin{array}{c}\text { Du Gundan } \\
\text { Bejeek }\end{array}$ & 180 & 18 \\
\hline \multirow[t]{4}{*}{7} & bardarash & & Garbadu ni & 106 & 11 \\
\hline & & Rovia & Dulijan Bjeik & 364 & 36 \\
\hline & & & Ismawa & 858 & 86 \\
\hline & & & Total & 4740 & 474 \\
\hline
\end{tabular}

The names of the rural women in the targeted village were obtained from the local Administrations. A total of 474 women were randomly selected.

\section{RESULTS AND DISCUSSION}

\section{Identify the economic participation level by rural women in Duhok Governorate / Kurdistan region of Iraq.}

Table (2) shows the rural women in Duhok Governorate are divided into three categories. Form table (2) it reveals that (30.169\%) (143) of the respondents have high level of economic participation. The table also shows that $(47.257 \%)$ (224) have moderate level of economic participation, and only (22.574\%) (107) of the respondents have low level of economic participation, may be the reason is that women participation in agriculture and economic activities make them self-reliant and enhances their empowerment status within the family and community in general.

Table (2): Shows distribution of respondents according to the level of Economic participation

\begin{tabular}{cccc}
\hline Economic participation & Frequency & Percentage & participation Mean \\
\hline (16-26) Low & 107 & 22.574 & 22.169 \\
\hline (27-37) Moderate & 224 & 47.257 & 32.491 \\
\hline (38-48) High & 143 & 30.169 & 41.860 \\
\hline$\overline{\mathrm{X}}=32.993$ & 474 & 100 & \\
& Total & \multicolumn{3}{c}{$\mathrm{sd}=7.745$}
\end{tabular}

According to Table (3), items of respondent's participation in economic work were ranked based on their mean values. Respondent's participation level towards the item, "I sure to cut home expenses" is ranked the highest mean value which was (2.592). This may be due to the difficult economic conditions experienced by families in the region, especially the 1990s 
(economic blockade), and therefore rural women seek to reduce the expenses of the house and provide them in anticipation of similar circumstances. While such item as, "I present to the officials proposals for development projects for the region" ranked the lowest mean value (1.582). This means that most of the respondents have not face problems with financial.

Table (3): Distribution of respondents according to the scale of economic participation

\begin{tabular}{|c|c|c|c|c|c|c|c|c|c|}
\hline \multirow[t]{3}{*}{ No. } & \multirow[t]{3}{*}{ Items } & \multicolumn{6}{|c|}{ Degree of participation } & \multirow[t]{3}{*}{ mean } & \multirow[t]{3}{*}{ rank } \\
\hline & & \multicolumn{2}{|c|}{$\mathrm{Big}$} & \multicolumn{2}{|c|}{ Medium } & \multicolumn{2}{|c|}{ Few or Non } & & \\
\hline & & No. & $\%$ & No. & $\%$ & No. & $\%$ & & \\
\hline 1 & I sure to cut home expenses. & 329 & 69.4 & 97 & 20.5 & 48 & 10.1 & 2.592 & 1 \\
\hline 2 & $\begin{array}{l}\text { I participate the family in the savings and savings of the home } \\
\text { budget }\end{array}$ & 292 & 61.6 & 129 & 27.2 & 53 & 11.2 & 2.504 & 2 \\
\hline 3 & I participate the head of household in the home budget. & 284 & 29.9 & 119 & 25.1 & 71 & 15.0 & 2.449 & 3 \\
\hline 4 & I would like to contribute to rural handicrafts. & 211 & 44.5 & 173 & 36.5 & 90 & 19.0 & 2.255 & 4 \\
\hline 5 & I contribute to increased family income through plant products & 223 & 47.0 & 148 & 31.2 & 103 & 21.7 & 2.253 & 5 \\
\hline 6 & Provide material assistance to poor families in the village. & 187 & 39.5 & 210 & 42.4 & 86 & 18.1 & 2.213 & 6 \\
\hline 7 & $\begin{array}{l}\text { I contributed to increasing family income through animal } \\
\text { products. }\end{array}$ & 201 & 42.4 & 154 & 32.5 & 119 & 25.1 & 2.173 & 7 \\
\hline 8 & Keen to participate in the food industry in the village. & 164 & 34.6 & 199 & 42.0 & 111 & 23.4 & 2.111 & 8 \\
\hline 9 & Participate in manual labor to increase income & 182 & 38.4 & 122 & 25.7 & 170 & 35.9 & 2.025 & 9 \\
\hline 10 & Participate in home economics training courses. & 121 & 25.5 & 162 & 34.2 & 191 & 40.3 & 1.852 & 10 \\
\hline 11 & Participate in the marketing of agricultural products. & 111 & 23.4 & 176 & 37.1 & 187 & 39.5 & 1.839 & 11 \\
\hline 12 & $\begin{array}{l}\text { Participate in the fields of work available in the village and } \\
\text { generate additional income }\end{array}$ & 103 & 21.7 & 189 & 39.9 & 182 & 38.4 & 1.833 & 12 \\
\hline 13 & $\begin{array}{l}\text { I sure to follow radio and television programs that are } \\
\text { concerned with home economics }\end{array}$ & 98 & 20.7 & 195 & 41.1 & 181 & 38.2 & 1.824 & 13 \\
\hline 14 & $\begin{array}{l}\text { I make recommendations to improve the economic situation of } \\
\text { families }\end{array}$ & 104 & 21.9 & 166 & 35.0 & 204 & 43.0 & 1.789 & 14 \\
\hline 15 & $\begin{array}{l}\text { I participate in economic development programs organized by } \\
\text { the agricultural people or international organizations in the } \\
\text { region. }\end{array}$ & 68 & 14.3 & 193 & 40.7 & 213 & 44.9 & 1.694 & 15 \\
\hline 16 & $\begin{array}{l}\text { I present to the officials proposals for development projects for } \\
\text { the region. }\end{array}$ & 75 & 15.8 & 126 & 26.6 & 273 & 57.6 & 1.582 & 16 \\
\hline
\end{tabular}

\section{Identify the relationship between selected characteristics of rural women and their degree of participation economic activities.}

Pearson's and spearman correlation were used to examine the association between independent variables and degree of economic participation of respondents. Based on the results presented in Table (4), there is a significant correlation between each of (age, number of study years, satisfaction with services in the village, urban openness) with the economic participation of respondents in study area.

"Age" has a positive significant relationship with the economic participation of respondents the number of Person correlation value 0.132 this was significant at 0.01 . The reason may be due to accumulated experience and increased awareness of the importance of participating in economic activities to improve their position within the family and society.

Follow by, "number of years of study" has negative correlation with the economic participation of the respondents, the number of Person correlation value 0.210 - this was significant at 0.01 may be the reason is that the majority of rural women in the targeted area are illiterate or fall into the low level of education.

Other characteristic is "satisfaction with services in the village" the results show that there is a positive correlation with economic participation, the number of Person correlation value 0.158 this was significant at 0.01 may be the reason for that when the respondents have high satisfaction with services in the village this 
will encourage them to economic participation, and "of course" benefits from variable economic opportunities in their villages.

Other characteristic is "urban openness" shows that there is a positive correlation with economic participation may be the reason is that more visits and more media contact one have the more aware on economic activities in their local communities, that contribute to raising the level of participation of rural women in economic participation as part of rural development.

Table (4): The Correlation between selected characteristics of rural women and their economic participation

\begin{tabular}{|c|c|c|c|c|c|}
\hline No & Variables & $\begin{array}{l}\text { Person correlation } \\
\text { value }\end{array}$ & $\begin{array}{l}\text { Spearman correlation } \\
\text { value }\end{array}$ & Sigma value & Sig. \\
\hline 1 & Age & 0.132 & & 0.004 & ** \\
\hline 2 & Number of study years & $0.210-$ & & 0.000 & ** \\
\hline 3 & Living Conditions of the Family & & 0.040 & 0.380 & ns \\
\hline 4 & Father's occupation or guardian & & 0.074 & 0.109 & ns \\
\hline 5 & current job & & $0.018-$ & 0.602 & ns \\
\hline 6 & Ability to solve problems & 0.067 & & 0.143 & ns \\
\hline 7 & Satisfaction with services in the village & 0.158 & & 0.001 & ** \\
\hline 8 & Urban openness & 0.521 & & 0.000 & ** \\
\hline
\end{tabular}

3. To diagnose the obstacles of economic participation by rural women in Duhok governorate / Kurdistan region of Iraq.

Table (6) shows the obstacles facing economic participation of rural women that the obstacle (High unemployment rates) is ranked first with an arithmetic mean (2.713), and that of (Women's economic dependency) occupied the last rank with an arithmetic mean (2.156)

Table (6): The Distribution of respondents according to the Obstacles facing economic participation of rural women

\begin{tabular}{|c|c|c|c|c|c|c|c|c|c|}
\hline \multirow[t]{3}{*}{ No. } & \multirow[t]{3}{*}{ paragraphs } & \multicolumn{6}{|c|}{ Degree of participation } & \multirow[t]{3}{*}{ Mean } & \multirow[t]{3}{*}{ rank } \\
\hline & & \multicolumn{2}{|c|}{ Big } & \multicolumn{2}{|c|}{ Medium } & \multicolumn{2}{|c|}{ Few or Non } & & \\
\hline & & No. & $\%$ & No. & $\%$ & No. & $\%$ & & \\
\hline 1 & High unemployment rates. & 364 & 76.8 & 84 & 17.7 & 26 & 5.5 & 2.713 & 1 \\
\hline 2 & $\begin{array}{l}\text { Lack of material support for economic participation } \\
\text { by the official authorities. }\end{array}$ & 330 & 69.6 & 110 & 23.2 & 34 & 7.2 & 2.624 & 2 \\
\hline 3 & $\begin{array}{l}\text { The social situation does not encourage economic } \\
\text { participation. }\end{array}$ & 265 & 55.9 & 179 & 37.8 & 30 & 6.3 & 2.495 & 3.5 \\
\hline 4 & Fear of losing money. & 267 & 56.3 & 175 & 36.9 & 32 & 6.8 & 2.495 & 3.5 \\
\hline 5 & $\begin{array}{l}\text { Weak financial resources for women's } \\
\text { organizations. }\end{array}$ & 279 & 58.9 & 143 & 30.2 & 52 & 11.0 & 2.479 & 5 \\
\hline 6 & Economic recession. & 240 & 50.6 & 183 & 38.6 & 51 & 10.8 & 2.398 & 6 \\
\hline 7 & $\begin{array}{l}\text { Lack of adequate education on the importance of } \\
\text { economic participation. }\end{array}$ & 227 & 47.9 & 208 & 43.9 & 39 & 8.2 & 2.396 & 7 \\
\hline 8 & $\begin{array}{l}\text { Women's sense of psychological and physical } \\
\text { instability. }\end{array}$ & 225 & 47.5 & 202 & 42.6 & 47 & 9.9 & 2.375 & 8 \\
\hline 9 & Weak momentum of economic participation. & 201 & 42.4 & 223 & 47.0 & 50 & 10.5 & 2.318 & 9 \\
\hline 10 & Women's economic dependency. & 141 & 29.7 & 266 & 56.1 & 67 & 14.1 & 2.156 & 10 \\
\hline
\end{tabular}




\section{CONCLUSIONS \& RECOMMENDATIONS//I///In brief, The} economic activities is one of the most important factors which can increases the ability of rural women by giving them new courses or new training to make them more able to resolve their problems, therefore in this research the results indicated that the majority of rural women in

Duhok Governorate that (30.169\%) (143) of the respondents have high degree of economic participation level. The study results also reveals that the (4) greatest variables, hindering rural women participation in the targeted area, which are between (age, number of study years, satisfaction with services in the village, urban openness). Based on the results and observations made during the survey, it was clear that the participation of women in most areas is still less than the expectations. ///////Based on the results of this study, the following recommendations were made:

1- Agricultural extension agencies in the targeted area should encourage and cooperative the rural women to participated and be members of civil society institutions and NGOs or CBOS (Community based organizations).

2- The extension agencies should have a reorientation of their Programs and activities, where women will be treated equally with their male counterparts. This will ensure more rural and agricultural development in the targeted area 3- Create an environment that encourages rural women's increased participation in extension, household decision-making.

4- Awareness raising program about the importance of rural women's participation should be made both for males and females. Religious and rural leaders, women associations, civil societies, NGOs and mass media can play vital roles.
5- Develop and promote personal skills training courses for rural women on leadership, publicspeaking, family planning, decision-making, and self-assertion;

6- Expectations it is necessary to improve their participation in decision-making to enhance their empowerment as well as their status in the community.//I////REFERENCES//II////Adisa

Banji Olalere. 2013. An Assessment of Participation of Rural in Community Based Development Activities (CBDs) in Osun State, Nigeria. Journal of Sustainable Development in Africa, Vol. 15, No. 7.

Salih, Chawan, Mohammed, 2015. Some factors affecting the local participation of rural women in halabja governorate, master thesis, university of sulaimani.

Das, 1995. Food and Agriculture Organization of the United Nations [FAO].Governorate. College of Agriculture- Ain Shams University/Egypt.

Harbi, Miryam Ali Salim 1997. A Sociological study of women Participation in Egyption rural Area. College of Agriculture, Al-Azhar University, Egypt.

Jonathan Temple and Paul A. Johnson. 1998. Social Capability and Economic Growth. Source: The Quarterly Journal of Economics, Vol. 113, No. 3, Pp. 965-990.

Sherif, Dowaa Mohamed Mohamed Saleh 2005. Some Social Factors Affecting the Degree of Rural Women Political Participation in Qualubia Governorate. College of AgricultureAin Shams University/ Egypt.

World Bank, 2008. Gender in Agriculture, Agriculture and Rural Development.

Yousef Ghanbari1, Hamid Barghi2, Nafiseh Ghotbinejad3, 2013. Participation of rural women in the agricultural sector and their impact on sustainable development (Case study of rural women in big part of Kashan city). International Research Journal of Applied and Basic Sciences. Science Explorer Publications. Vol. 6, (6): 761-765. 


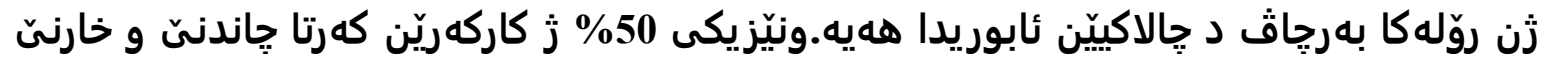

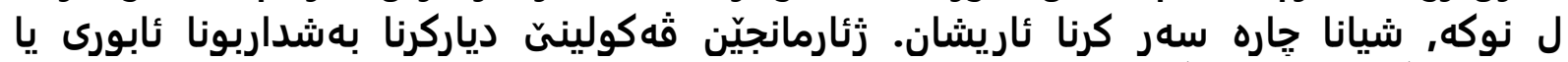

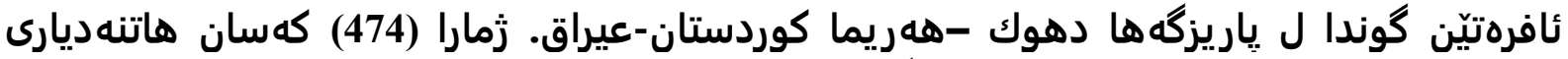

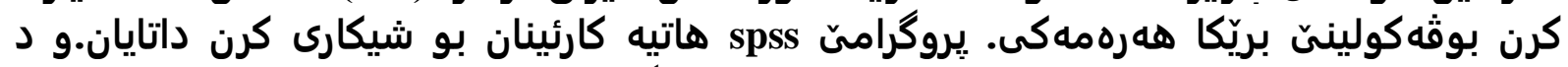

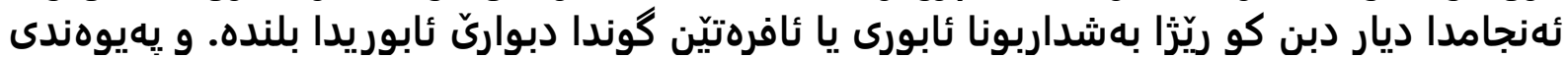

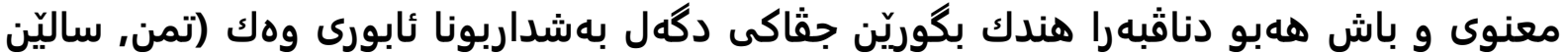

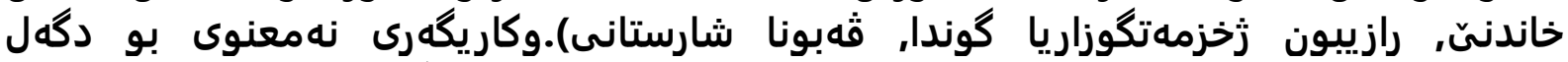

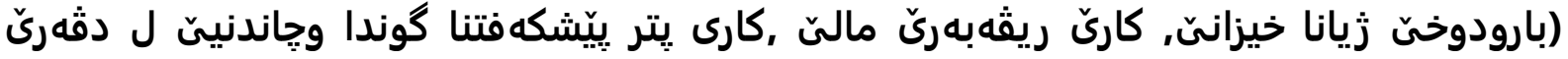

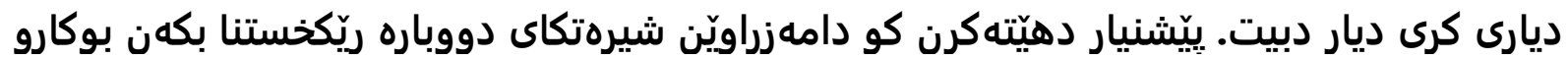

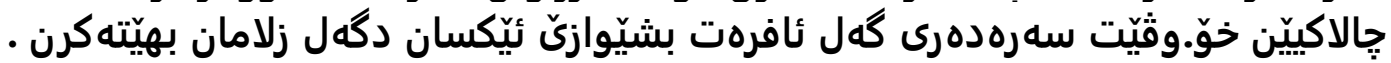

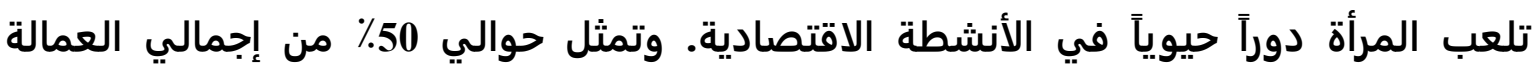

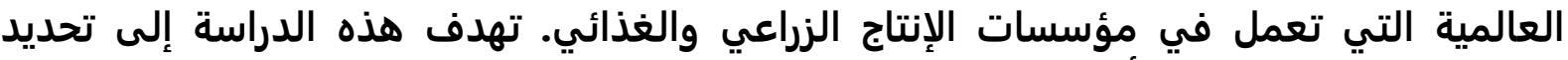

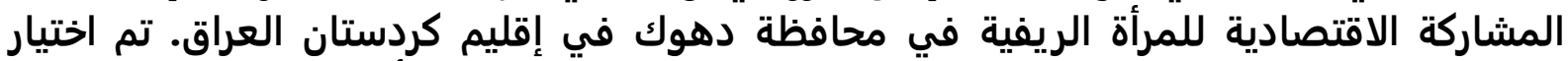

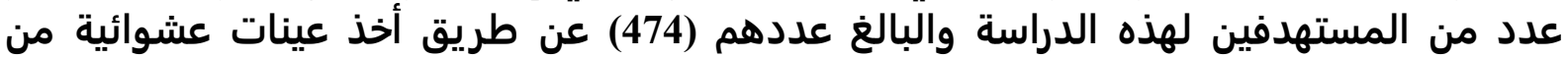

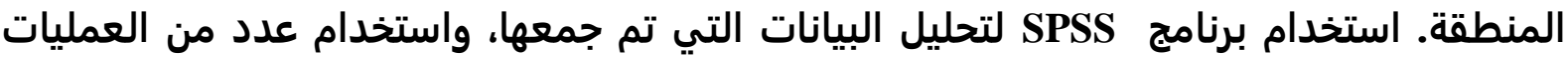

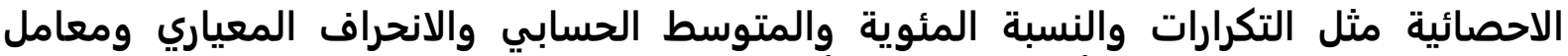

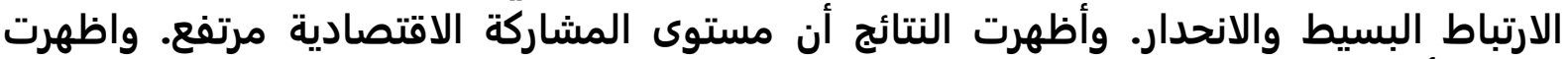

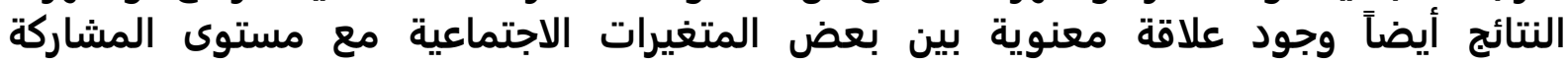

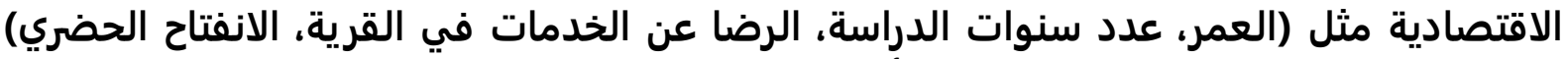

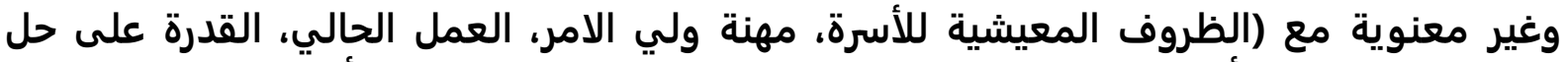

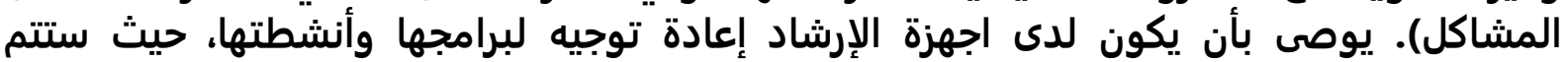

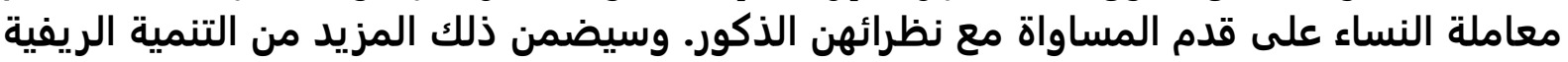
والزراعية في المنطقة المستهدفة. 